\title{
ECOLOGICAL ASPECTS OF SPATIAL ORIENTATION
}

\author{
Rudolf Jander \\ Department of Systematics and Ecology, Department of Entomology, University of \\ Kansas, Lawrence, Kansas 66045
}

\section{INTRODUCTION}

Despite the immense body of literature concerning animal orientation, little previous effort has been made to prepare a comprehensive discussion and unified theory of orientation ecology, the subdiscipline at the interface between ecology and ethology. Much of the existing orientation literature is widely dispersed, found partially in explicit studies on orientation and partially in countless publications about life histories. In this review, in order to organize this hidden scientific treasure and to facilitate access to it, the concept of orientation ecology is defined, then the subdiscipline is naturally divided into six categories. Finally, within these categories, predictive generalizations or rules, based on induction, deduction, and intuition are formulated. All these rules and principles are preceded by consecutive bold numbers in square brackets to facilitate recognition.

\section{INFORMATIONAL RESOURCES AND STRESS SOURCES}

Central themes of any ecosystem analysis are the competitive interactions between organisms as they strive for access to, control of, and use of limited resources. A resource is most broadly defined as any spatiotemporally patterned probiotic or life-supporting factor such as the directional force of gravity or the patterned distribution of prey.

Resources fall into two inclusive and largely disjunct groups: trophic (i.e. primary) and informational (i.e. secondary). The former, as used here, includes both materials and energy. The latter comprises all environmental factors that have negligible direct effects on the energy and materials budgets of living systems or their subsystems, but that are capable of modifying the internal states of organisms. Therefore, informational resources act in a very broad sense as stimuli.

General ecological texts are typically preoccupied with trophic ecology and rarely mention information ecology or informational resources, despite the fundamental role information flow plays in the functional structure of ecosystems. This role is strikingly obvious in man's incisive interaction with the whole biosphere through 
his use (and misuse) of information. Specialized utilization of informational resources, however, is by no means restricted to man. In fact, organisms at the simplest known free-living organizational level, such as Escherichia coli, have been shown by differential effects of mutations to contain two functionally distinct subcellular systems, one for handling trophic resources (nutrients, metabolites) and another for informational resources (3). The latter system detects chemical gradients and thereby controls movements in space.

[1] In general, all living organisms contain distinct mechanisms (subsystems) for dealing with informational resources. For instance, green plants have the phytochrome system (111) or the abscissic acid (ABA) system (107), and higher animals have a neurosensory system for receiving, processing, and emitting information. In order to gain proper insight into ecological relationships, it is necessary that our conceptual classification of resources be so structured as to match the differentiation into trophic and informational subsystems within organisms.

Discussion of resources alone does not result in adequate accounts of speciesspecific environments or niches. The new complementary concept of stress sources has to be added because the spatiotemporal distribution of stress sources is frequently not merely the negative of that of resources. Stress sources also have informational importance.

Because all spatial and temporal orientation is mediated by informational subsystems of organisms, orientation ecology belongs to the neglected area of information ecology. All behavioral information utilized by motile organisms falls into two large classes: "know how," controlling instrumental behavior, and "know when and where," controlling orientational behavior. Behavioral ecology is essentially the understanding of the adaptive significance of such activities in natural environments. Pertinent reviews are rare. Klopfer's (93) account stresses instrumental behavior. As for temporal orientation, several reviews may be consulted $(20,40,108)$. Least covered, to date, is spatial orientation, to which modern texts on general ecology or general ethology rarely give organized attention.

\section{THE CONCEPT OF ORIENTATION AND SOURCES OF BEHAVIORAL INFORMATION}

The latest account of invertebrate orientation is by Carthy (25); the latest comprehensive coverage of animal orientation appeared in 1940 in the landmark book by Fraenkel \& Gunn (47). This synthesis is now quite out of date in most respects because most of the literature about orientation is younger. Nonetheless, the majority of contemporary writers on orientation still employ the old conceptual and theoretical framework. For the ecologist, additional difficulties arise from the fact that the phenomena of orientation are mainly described in terms of mechanisms and sensory modalities rather than ecological relevance. The following reasoning resolves this dilemma.

Ever since Kühn (96) defined taxis as a turning response, most authors designate any act of spatial orientation by this term. This traditional conception, however, is much too narrow in two ways. 
First, it is a simple geometric fact that bodies in space do not move only by rotation but also by translation. Hence spatial orientation is composed of both directional and distance orientation, with three degrees of freedom of movement for either case. By taking these fundamental geometric properties into account, spatial orientation should now properly be defined as self-controlled maintenance or change of body position relative to the environmental space (80). "Self-controlled" rules out passive transport, and "maintenance of body position" refers to spatial movements counteracting passive transport or tilting.

Second, spatial orientation is inconceivable without sources of spatial information. Instantaneous sensory spatial information was generally presumed to be the exclusive source of spatial orientation until it was realized that certain broad categories of behavioral information are involved in both the control of instrumental behavior and the control of spatial orientation $(80)$. Thus to predict spatial orientation, it is necessary to discriminate between immediate sensory information (extrinsic orientation) and centrally stored information (intrinsic orientation); the terms exokinetic orientation and endokinetic orientation carry the same respective meanings (80). Much of what has formerly been called "kinesthetic orientation"-falsely implying proprioreceptors as sources of information-is now more appropriately called intrinsic orientation, since proprioreceptors only mediate spatial information and definitely do not generate or store it. Where sufficient evidence is available, internally stored spatial information is further subdivided into innate (i.e. instinctive) and memory information. Examples are given later.

Deterministic information, that is, information that renders behavior predictable, is limited, and since there are also situations in which orienting in a predictable way is disadvantageous, various portions of all orientation have to be stochastic or "noisy." In line with this reasoning, more and more ethologists have come to recognize that the classical goal of understanding behavior in terms of causation only must be supplemented by the use of probabilistic models.

\section{ORIENTATION FITNESS AND ITS CONSTRAINTS}

The meaning of orientation ecology can be developed from the concept of spatial orientation and some basic ecological facts. It is recognized that the whole biosphere at all levels of structure down to microscopic dimensions is spatiotemporally patterned $(71,102,126)$. Organisms have adapted their orientation to their particular environments through selection. Based on these premises, and disregarding various constraints listed below, the fundamental term orientation fitness is defined as the ability of an organism to minimize its distance from resources and maximize its distance from stress sources; in sum, orientation fitness is its ability to be in the right place at the right time. The orientation ecologist then wants to know how and how well the orientation systems of organisms match the spatiotemporal structures of their niches.

Four types of constraints must be considered in developing and understanding principles of and generalizations about orientation ecology by means of the concept of orientation fitness. 


\section{JANDER}

First are organizational constraints. [2] Because the complexity of any organism's internal system is finite and the dimensional structure of any environment is infinitely complex, the orientation fitness of all organisms has to be suboptimal. [3] The smaller an organism, the simpler its orientation system can be expected to be, because miniaturization of functional elements (neurons, receptors, etc) is limited $(120,121)$. [4] Since evolution invariably takes time, a newcomer to an environment is likely to have a less well adapted orientation system than an ancient, established species. Thus Hospitalitermes sharpi, a nasute termite that turned relatively recently to open-air foraging, has the simplest topographic orientation system known among social insects, whereas similarly foraging ants disply a highly sophisticated counterpart $(75,82,140)$. [5] Frequently, when a series of species employs increasingly complex orientation systems to handle a given orientation problem, it will be found that the more elaborate systems will contain the simple systems as functional components. Examples are given in the sections about the categories of orientation. [6] Because evolution proceeds gradually, because orientation fitness increases with system complexity, and because the foregoing rule [5] holds, successive levels of increasing orientation complexity may be taken as models for successive evolutionary steps (78).

The second type of constraints arises from the fact that each movement in space has its cost in terms of expended time and energy. [7] Costs and benefits have to be weighed against each other when trying to predict orientation strategies with respect to stress sources and resources such as food $(38,58,64,131)$.

Third, during the evolutionary process many aspects of overall fitness may interfere with orientation fitness. [8] An organism selected for small size will have a reduced orientation complexity according to rule [2]. [9] The more sedentary an organism, the simpler its orientation system. Wingless aphids, maximizing the rate of feeding, metabolism, and reproduction, lack visual escape orientation from predators, a common response among mobile insects of their size. Barnacles irrevocably lose all orientational abilities once their cypris larvae attach themselves to the substrate (44). [10] Strictly nocturnal animals, such as the insectivorous bats, or subterranean species, such as the cave fish Anoptichthys jordani, tend to simplify their light orientation system as compared to their diurnal allies (88).

A fourth type of constraints involves alternatives to flight orientation away from stress sources. [11] Organisms with repellents or poisons (skunks, wasps) can afford to reduce their escape behavior. Diapause and hibernation are common alternatives to long distance migrations for inhabitants of temperate climates.

\section{SOME GENERAL RULES OF ORIENTATION ECOLOGY}

In addition to the generalizations related to various constraints, some overall rules are concerned with the dependence between orientation fitness proper and the four basic types of behavioral information sources: instantaneous environmental, memory, innate, and stochastic. [12] It is now widely acknowledged that combinations of these informational sources always contribute to the control of a particular behavior; yet the nonrandomness of these combinations is rarely stressed. This general statement may be expanded as follows: [13] Organisms tend to "know" 
innately the highly redundant and simple spatial properties of environments. [14] For instance, virtually all motile organisms innately know to turn about $180^{\circ}$ or reverse their locomotion when sign stimuli indicate approach to a stress source or avoidance of a resource. Rhodospirillum rubrum, a sulfur bacterium, reverses its swimming direction upon entering a dark or very bright zone (26). Various jellyfish (e.g. Scyphozoa), when swimming upward, reverse their gravity-controlled direction upon mechanical disturbance (69). Young wood ants (genus Formica), marching straight away from the nest site for the first time, under the guidance of learned light compass orientation, instinctively reverse the direction of their light orientation at the end of the journey (75). Courting male crickets and cockroaches turn $180^{\circ}$ without prior experience so the females can climb their backs $(6,12)$.

Innate knowledge of more complex spatial attributes of environments is shown by other examples. Ant-lions (genus Myrmeleon) dig circular grooves as first steps in pit construction (151). Garden warblers (Sylvia borin) raised in captivity demonstrate innate knowledge of geographic spatial relations by heading properly southwest with respect to the earth's magnetic field for their first fall migration (150). Similarly, beach hoppers (Talitrus saltator, Amphipoda), prior to individual experience, know according to the orientation of their native beach which sun compass direction to take up in order to escape from water (114).

[15] Highly redundant but complex, as well as moderately redundant, spatial information about environments is learned, provided the organizational level of the organism permits such learning. For example, some birds learn stellar constellations $(39,144)$, and the familiarity of many vertebrates with their particular home ranges is widely known.

Quite often, and for various reasons, motile organisms lack all three predictive sources of information-innate, memory, and sensory-concerning the location of a vital resource. [16] In such situations of ignorance, organisms generally do not cease orienting but rather orient randomly. In other words, they generate low grade or "new" spatial information that increases their chances of locating the resource. How such free decisions are reached is still unknown; a reasonable hypothesis is that they are made by amplification of internal noise (synaptic noise, etc). Examples are provided under search behavior in the category of object orientation and under dispersal in the category of geographic orientation.

\section{ECOLOGICAL CATEGORIES OF SPATIAL ORIENTATION}

Because the time-honored Kühn-Fraenkel \& Gunn scheme of taxes and kineses has been shown to be inadequate, a new conceptual framework will be helpful in better organizing the more specialized principles of orientation ecology. The first criterion is whether a motile organism stays in place and position or moves on. In the former case, various disturbances (passive linear or rotational displacement) have to be counteracted. Such compensatory maneuvers are referred to as positional orientation.

Second, noncompensatory movements in space can be further subdivided with respect to the spatial patterning of resources and stress sources. Such sources may be either restricted to spots or patches in space, or they may stretch out in at least 


\section{JANDER}

one dimension. In the former case, the sources are called objects and the spatial orientation related to them is termed object orientation.

Third, various spatially extensive environmental factors frequently exhibit rather characteristic and predictable vertical and horizontal distributions or gradations. The former situation is referred to as stratification (layering) and the latter as zonation. Orientation with respect to these two spatial attributes is called strato (stratal) orientation and zonal orientation respectively.

Fourth, the environment within the routine activity range of an individual is frequently temporally rather stable and has a spatially unique constellation of resources and stress sources. Learned spatial orientation with respect to such unique spatial properties of a home range is called topographic or home range orientation.

Finally, motile organisms for various reasons may not stay within a circumscribed space, but instead may disperse or migrate over considerable distances. Orientation associated with such far ranging movements is called geographic orientation.

Habitat orientation is not listed in this classification because it overlaps all the other major categories.

\section{POSITIONAL ORIENTATION}

[17] Positional orientation manifests itself in swimming, flying, and large terrestrial walking organisms primarily as a means of counteracting the pull of gravity by orienting the body axes in such a way as to render the locomotory counterpush most effective. Similarly, benthic aquatic and small, surface-moving terrestrial organisms, by virtue of the reduced effects of gravitational pull, position themselves in cases of discrepancy with the ventral side toward the substrate rather than downward. [18] With the exception of the smallest unicellular forms, all freely swimming and flying organisms have mechanisms for positional orientation. [19] Because of their small size, motile bacteria are little displaced by the pull of gravity and their internal substructures are even less so. Thus, for physical reasons alone, they are unlikely to possess gravity sensors and gravity orientation $(117,123)$.

To understand the following details of positional orientation in eucaryotes it is necessary to recall that motile organisms possess six degrees of freedom of motion. Positional orientation may therefore neutralize either linear displacement (drift) or angular displacement, in particular pitch, the rotation around the transverse axis, and roll, the rotation around the longitudinal axis. Furthermore, positional orientation does not require an animal to be totally stationary; it may instead freely move within some of its six degrees of freedom of movement while stabilizing the rest.

[20] In unicellular and oligocellular swimming eucaryotes, positional orientation occurs only in rudimentary form. [21] Being propelled by flagella or cilia, most of these organisms rotate continuously about their longitudinal axis, thus obviating the need for roll stabilization $(94,101)$. [22] With their specific weight normally different from that of the aquatic medium (typically heavier) small eucaryotes tend to align their longitudinal axis vertically so that their main (rearward) thrust counteracts gravity-induced sedimentation. [23] Freshwater protozoa, for instance, such as the thoroughly studied Paramecium, are typically so shaped that their "head up" 
position is mechanically the most stable due to hydrodynamic torque, with the result that upward swimming predominates (123).

[24] As aquatic animals increase in size and concomitant dorso-ventral differentiation, the positional orientation changes from a predominantly vertical alignment of the longitudinal axis to a predominantly horizontal alignment. Provided the postembryonic ontogeny covers the appropriate size range, this change in positional orientation can be observed during the development of single individuals.

[25] In most Crustacea that hatch as nauplius larvae, such as Artemia salina, this switch from predominantly vertical to horizontal alignment coincides with the appearance of the compound eyes and the thoracopods at the end of the naupliar phase (78).

[26] Aquatic vertebrates and insects typically assume a horizontal position as soon as they hatch. [27] Those that do not immediately position themselves horizontally, such as the common herring and the tropical fish Badis badis (Nandidae), have early larvae, quite analogous to Artemia, that tend to maintain a vertical position and turn horizontally after yolk consumption $(11,16)$.

[28] Medium- to large-sized swimming animals of various phyla-annelids, molluscs, arthropods, chaetognaths, and vertebrates-typically confine most of their active displacements to horizontal planes or strata $(76,132)$. This is achieved by advanced positional orientation, that is, the stabilization of pitch, roll, and vertical drift. Such advanced aquatic positional orientation allows free movement and orientation in the forward direction and around the vertical axis.

[29] Most swimming Crustacea and vertebrates stabilize pitching and rolling by means of twin mechanisms: transverse gravity orientation and transverse light orientation $(76,81,132,134,137)$. [30] The relative importance of these two sensory orientation modalities is highly variable, even in particular individuals, depending in all cases studied on the light intensity, attention (in fish), and other factors (68, $76,134)$.

Differential weighing of the two modalities of positional orientation manifests itself in artificial as well as natural situations whenever gravitation and illumination are not well opposed. [31] If the main illumination comes from the side instead of the top, all species with twin orientation mechanisms turn their dorsal surfaces more and more towards the light as brightness increases. If the main illumination comes from below, the animal must decide whether to swim normally or upside down. Accordingly, in the famous Blue Grotto of Capri, Italy, fish may be seen swimming in various odd positions, even upside down, as determined by the various directions from which the brightest light reaches them (1).

[32] Swimming species with only one mechanism for positional orientation usually use transverse gravity orientation, as does Cyclops (Copepoda) (78), tadpoles of bull frogs (unpublished observations), and other Anura (74).

Not enough is known about the positional orientation of flying animals. Dragonflies, locusts, and Lepidoptera exhibit a dorsal light orientation while flying $(42,50$, $57,67,110$ ) and pigeons have recently been shown to utilize a supplementary gravity receptor located in their intestines (33). Only locusts are yet known to stabilize their flight position by visual reactions to the inclination of the horizon (50). 


\section{JANDER}

Transverse light orientation and transverse gravity orientation are the most widespread, but not the only, mechanisms stabilizing swimming and flying positions. [33] All vertebrates and a yet undetermined number of higher Crustacea and cephalopods counteract angular acceleration by use of semicircular canals and analogous organs $(19,35,128,129)$. [34] Angular acceleration as well as angular motion is also visually perceived and then counteracted by so-called optomotor reactions in all animals capable of high visual resolution, ranging from molluses to arthropods and vertebrates $(35,37,52,145)$. [35] Finally, for the purpose of stabilizing flight position $(118,130)$, only the Diptera are known mechanically to sense angular acceleration and angular motion by means of rapid oscillations of their halteres.

[36] When swimming animals and flying insects settle on solid ground, tactile stimuli override the positional control of light and gravity on the tilt of the dorsoventral axis $(73,139)$. The resulting mechanical orientation of the ventral surface toward the substrate allows the nontactile control of pivoting around the dorsoventral axis (yaw). [37] Virtually all terrestrial animals resting on vertical surfaces tend to maintain typical positions, most frequently head-up or head-down. [38] In at least one species of stick insect and several species of butterfly, this aspect of the resting position is controlled by both the direction of gravity and the direction of the main illumination $(13,147)$. It is frequently difficult to ascribe specific adaptive functions to the various resting positions of insects. [39] Cryptic insects, however, very clearly tend to position themselves in such a way that they blend with their environment $(29,124,127)$. [40] Large moulting insects, staying in the vegetation, position themselves in such a way that gravity supports them. For instance, both the locust Schistocerca americana and the butterfly Heliconius charatonius slide out of their old cuticle in a head-down position and then turn around so that the still soft and wrinkled wings expand in the direction of gravitational pull (unpublished observation).

Of the many more specialized functions that positional orientation may serve, only three are mentioned. [41] Virtually all animals that can rotate their eyes, their heads, or both, tend to stabilize the eye position relative to the visual environment by properly responding to any combination of visual, gravitational, and angular motion stimulation (35, 37, 50, 81, 109, 125, 145). The dragonfly Aeschna cyanea, for instance, banking while flying a curve, keeps its head in a perfectly upright position (89). Man, like animals with high visual resolution, follows the displacements of his visual environment by nystagmic eye and head movements. Maintaining the eye position relatively constant with respect to the vertical direction, irrespective of body position, facilitates the recognition of visual patterns that contain features related to the direction of gravity, and the nystagmus increases visual resolution by reducing blurr $(15,18,125)$.

[42] Terrestrial animals in suitable habitats, such as locusts, butterflies, lizards, or marmots, utilize body position for temperature regulation by exposing a large body surface to solar radiation at suboptimal temperatures and a small surface at superoptimal temperatures $(7,46,63,142)$.

Positional orientation also implies compensation for translatory displacement. [43] Aquatic organisms typically head toward and act against currents that they detect either mechanically when touching the ground or visually when swimming 
in the open (61). [44] Similarly, flying animals that do not utilize wind as a means of transport, such as dancing mosquitoes (36) and commuting honey bees (65) tend to head upwind and thus compensate for drift.

[45] The widespread "cliff avoidance response" of terrestrial vertebrates is a well-known example of a largely innately developed positional orientation preventing fatal falls. Some recent studies pertain to gulls, rats, and human infants $(21,24$, 143).

\section{OBJECT ORIENTATION}

[46] Object orientation is the only category of behavior in general and of orientation in particular that is universally found in all motile organisms from bacteria to man. This universality, in conjunction with obvious general biological importance, leaves little doubt that object orientation is the very first type of behavior to have evolved. [47] In line with this inference is the fact that object orientation is the only behavior found in bacteria and many other microorganisms. It is possible to propound several fundamental and general principles of object orientation despite the immense number and diversity of objects and species of motile organisms involved. [48] In most instances two major orientation phases - search and approach (or avoidance)-are distinguishable. They are based on a motile organism having, on the one hand, insufficient, and on the other hand, precise, information about the spatial locations of resource (or stress source) objects. With virtually no such information available, straight ongoing movement (transecting) is the most efficient strategy, presuming the most likely distribution of resources to be patchy, as stressed by several authors $(103,136)$. [49] All motile organisms from bacteria to man utilize such a straight-line search, resorting to various and still incompletely known means.

[50] Microorganisms and oligocellular organisms, as mentioned in the section on positional orientation, spin around their longitudinal axes while swimming forward. This spinning effectively assures straight paths that could hardly be maintained by other intrinsic mechanisms because of inevitable asymmetries of body physiology and morphology. [51] Arthropods without information about resource locations commonly utilize visual stimuli to maintain straight courses. For example, true polarized light orientation is commonly used in aquatic arthropods for straight-line swimming (86). On land, a caterpillar (Thaumetopoea pityocampa) in search for a place to pupate may simply move straight away from the sun (48), whereas locust nymphs (Locusta pardalina) may proceed toward the sun (116). Such bidirectional basic light orientation (i.e. positive and negative phototaxis) has been shown to be a functional component of the more flexible (polydirectional) light-compass orientation that insects with more complex visual systems use for straight-line walking $(77,100)$. The many other possibilities for steering a straight search course extrinsically include wind-compass orientation and gravity orientation on slopes $(77,83,84$, 99). [52] Most arthropods and vertebrates in complex environments use "counterturning" for restoring their course after forced diversion $(22,51,106)$. This intrinsic type of orientation entails central storage of information about forced turns to be used later for controlling compensatory counterturns. 
No organism engaging in rectilinear search goes on indefinitely; conceivably, such behavior would be maladaptive by eventually taking the searcher out of his habitat. [53] Accordingly, blowflies on a table or flocks of finches in the Mohave Desert, like all searching organisms, continually and erratically turn between straight stretches, thereby avoiding returns $(27,34)$. This composite search orientation is termed ranging.

[54] All motile organisms stop ranging when they sense the proximity of a vital object. [55] If such an object cannot be precisely located, they generate another search pattern, local search, usually implemented as convoluted search. Convoluted search entails tangled, looping, intersecting paths without straight sections. Thus, bacteria such as Salmonella typhimurium swim erratically, or "tumble," after losing the direction up the concentration gradient toward a chemical resource or down the concentration gradient away from a stress source (repellent). In those situations, "missing or losing the proper direction along the gradient" is the message of object proximity (141).

Diverse motile eucaryotes from protozoa to vertebrates have been shown to exhibit local search behavior. For instance, the blowfly, the stickleback fish, the carrion crow, and the thrush all search for patches of food items. They take the presence of a piece of food as a token for food patch proximity and start local convoluted search $(14,30,34,135)$. Such local search is often called area-restricted search (95), a term that should be avoided because of possible confusion with ranging, which is also area-restricted.

Convoluted search is not the most adaptive type of local search in all situations. Important determinants are the shape and dimensions of the approach space, i.e. the space around an object from which it can be located by the searcher, and the shape and dimensions of the detection space, i.e. the area around the searcher within which it detects objects. For example, such an approach space as the pheromonal odor plume emanating downwind from a female moth in the form of an elongate cone is to be intercepted by the circular detection space of the flying male. The local search of the male moth is flying hither and thither in increasing amplitude across the wind, a search tactic that could hardly be improved upon (92).

The complete sequence of object orientation is terminated by the approach or avoidance phase following local search. [56] Typically, approach or avoidance takes a straight course guided by stimuli that pinpoint the object. In bacteria, such as the already mentioned Salmonella typhimurium, approach or avoidance is straight swimming up or down respectively along a perceived gradient of solutes (141). [57] A class of exceptions from this general rule is the erratic courses produced by fleeing animals closed in by pursuers, say kangaroos being hunted (90) or male houseflies chasing each other (97). Such stochastic movements in space (protean defense) (70) interfere with the ability of the pursuer to anticipate the pursued's next location.

It is not unusual for a motile organism to find itself in the approach and avoidance spaces of several objects at the same time. [58] In such situations apparently all species from bacteria to vertebrates compare by summation the positive and negative stimulus values of different intensity and "decide" from the result which objects to approach or to avoid $(4,79,85)$. [59] Such simultaneous as well as successive 
comparisons are possibly not the only explanations for the rule that approach selectivity decreases with interobject distances as shown in the plankton-feeding sunfish Lepomis macrochirus (148).

Numerous more restricted principles are superimposed on the fundamental principles of object orientation. Cropping orientation is an example. First appearing among worm-like animals, cropping orientation is largely an intrinsic orientation that in areas of contiguous or overlapping approach distances determines the particular path followed from object to object. [60] The characteristic subunit of a cropping path is a rather straight ongoing movement. On this are superimposed alternating movements to the left and right for objects within reach, such as in the "pendulum feeding" of snails (32). Frequently such straight cropping paths are combined into more complex patterns with "radial cropping" and "meander cropping" being the most prominent. [61] Animals that regularly return to a central refugium (refuging, 60) typically employ radial cropping; they fan out along straight paths, as described for some fiddler crabs (57). "Radial looping" is more elaborate and probably more efficient since the same ground is not covered twice; the animal moves away from its refugium and returns to it from a different direction, in a loop, as described in the fiddler crab $U c a$ maracoani and in baboons $(57,59)$. [62] Nomadic animals favor meander cropping in which at least one hair-pin turn is made, as observed, for instance, in mountain gorillas (45). A restricted area may be more or less tightly covered by alternating hair-pin loops or tight meanders, as in grazing snails, enteropneusts, stalked-eyed flies, and orangutans $(17,23,104,149)$. Radial cropping and meander cropping date back to Cambrian times, as numerous fossilized tracks document (56).

\section{STRATO ORIENTATION}

Strato orientation is only briefly mentioned here. [63] There are continuous massive migrations of organisms up and down through the omnipresent strata of the biosphere. The vertical directions are maintained by light and gravity. Best studied and reviewed are the diel vertical migrations of freshwater and marine zooplankton (8, $10,71,115,122$ ). Diel vertical migrations are also found in many terrestrial animals such as millipedes (55) and grasshoppers (5).

\section{ZONAL ORIENTATION}

Zonal orientation is the orientation across ecotones and along horizontal to subhorizontal ecological gradients. [64] Because vertical gradients are commonly steeper than horizontal ones, the relative importance of zonal orientation over stratal orientation increases with body size, a correlation well reflected in the corresponding change in positional orientation described by rules [22-28]. Best studied is the movement perpendicular to shorelines, sometimes referred to as $y$-axis orientation. Reviews are available for arthropods, Amphibia, and hatchling sea turtles $(41,43$, 66, 112). [65] Advanced cross-shoreline orientation, as found in many arthropods, contains time compensated sun-compass orientation as an essential component. A crude way of moving only approximately up or downshore is found in the littoral 
snail Nerita plicata, which simply changes between moving toward or away from the sun (i.e. basic orientation) at the proper time of the day (146). An example of moving along gradients is the downdrift of arthropods in running water being compensated by upstream migrations (113).

\section{TOPOGRAPHIC ORIENTATION}

Topographic orientation may be considered as an elaborated approach phase of object orientation, refined and extended by learning. What is learned are the spatial relationships (constellation) among objects and between objects and orienting subjects. One of the rudimentary forms of topographic orientation is the intrinsic return orientation of the spider Cupienus salei to the prey from which it has been chased (133). [66] Fragmentary knowledge suggests that short distance return orientation, as in the preceding example or in refuging animals such as fiddler crabs, is mediated by intrinsic orientation (57). The locomotory output during the outgoing path is somehow integrated and centrally stored, then the return path is controlled with this memorized information. However, funnel web spiders (Agelena) find the short return path on the web to the refuge not only by intrinsic return orientation but also by use of polarized light and directional light (51).

Best analyzed is the topographic orientation system of the honey bee (49). [67] Bees, like other homing Hymenoptera, record their foraging range by means of polar coordinates. In such a vector orientation, distance is controlled by an intrinsic mechanism, and direction by celestial- (sun and polarized light) compass orientation. Within this framework, bees, ants, and wasps (Vespidae, Sphecidae) learn the positions of conspicuous landmarks that they also use in their topographic orientation. The two parameters of the vector orientation-distance and direction-are communicated by the dance language of the honey bees (genus Apis) $(49,98)$.

[68] There is evidence that most, if not all, vertebrates are capable of topographic orientation. The experimental analysis of this capacity is still too fragmentary to establish general rules.

\section{GEOGRAPHIC ORIENTATION}

Geographic orientation partially intergrades with both object orientation and zonal orientation. No distinct borderline exists between the ranging phase of object orientation and dispersal orientation. The only change may be the increasing lengths of straight, ongoing movements. Dispersal, in turn, can be looked at as a rudimentary form of geographic orientation, a movement in a randomly selected direction in the absence of specified geographic information (31). [69] As travel distances increase, approaching or exceeding hundreds of kilometers, true geographic orientation emerges; directional randomness disappears and specified geographic information determines the movements. The absence of a distinct boundary between dispersal and true geographic orientation poses terminological problems (87). The adaptive significance of true geographic orientation is usually obvious, as in the seasonal migrations of birds. 
With regard to increasing sophistication of control, four levels of geographic orientation can be recognized in terrestrial animals, two for insects and two for birds. Minimal geographic orientation control is exhibited by migratory locusts, which ascend and descend in and out of trade winds that carry and guide them over vast distances (119). Cabbage butterflies (Pieris brassicae and P. rapae) in England do better in controlling their seasonal migrations by flying directly toward the sun in the fall and away from the sun in spring, thus simply utilizing basic directional light orientation (positive and negative phototaxis) (9). In their end result, such migrations are biologically meaningful, though not optimal because of the lack of linearity.

Really straight migrations may be controlled by visual celestial compass or magnetic compass orientation, as in the extrinsic component of geographic vector orientation in birds. [70] The associated distance orientation, as in the topographic vector orientation of bees and ants, is under intrinsic control (54). Navigation, finally, is the still-unexplained ability of birds with some experience to reach from an unknown location a geographic goal over medium to great distances. Several reviews of long distance bird orientation are available $(2,53,91,105)$.

Many fish migrations, especially up and down river systems, may be considered as extensions of zonal orientation. An important component of the geographic orientation of fish is following an odor-marked current of water, a form of guideline orientation $(28,62,138)$.

\section{CONCLUDING REMARKS}

For orientation ecology to flourish it is deemed essential that the still predominating classification of taxes and kineses be supplemented or replaced by terms with strong ecological connotations. The proposed unified theory and terminology of orientation ecology serves two main purposes: it organizes multitudinous phenomena from bacteria to man, thus rendering them more readily accessible, and it brings numerous details within reach of prediction by means of general rules and principles. A total of seventy such generalizations is marked by square brackets in this review, and only space limited the establishment of many more. From this, I venture to say that no other area of ecology or ethology of comparable scope is presently understood in such depth and breadth as orientation ecology, and this statement definitely holds for the interface between ecology and ethology. Apart from this, orientation ecology derives its importance from the fact that all motile organisms, while interacting with their environments, spend more time orienting than in any other similarly complex behavioral activity. In addition, orientation is the only universal behavior of all motile organisms. It is also of general importance that cropping paths, a subject of orientation ecology, are the best preserved complex behavior in the fossil record.

\section{ACKNOWLedgments}

I am indebted to Mr. E. M. Barrows, Dr. R. F. Johnston, Dr. C. D. Michener, Dr. W. J. O'Brien, Mrs. M. O'Brien, and Dr. O. Taylor for helpful comments on various 
parts of the draft. Most of my work on animal orientation had been supported by the "Deutsche Forschungsgemeinschaft"; it is presently supported by NSF Grant BMS 72-02575.

\section{Literature Cited}

1. Abel, E. 1953. Lichtrückenreflex eines Fisches in der blauen Grotte. Österr. Zool. Z. 4:397-401

2. Adler, H. 1970. Ontogeny and phylogeny of orientation. In Development and Evolution of Behavior: Essays in Memory of T. C. Schneirla, ed. L. R. Aronson, E. Tobach, D. S. Lehrman, J. S. Rosenblatt, 303-36. San Francisco: Freeman

3. Adler, J. 1973. Chemotaxis in Escherichia coli. In Behavior of MicroOrganisms, ed. A. Perez-Miraveta, 1-15. NY: Plenum

4. Adler, J., Tso, W.-W. 1974. "Decision"making in bacteria: chemotactic response of Escherichia coli. Science 184:1292-94

5. Alcock, J. 1972. Observations on the behaviour of the grasshopper Taeniopoda eques (Burmeister), Orthoptera, Acrididae. Anim. Behav. 20:237-42

6. Alexander, R. D., Otte, D. 1967. The evolution of genitalia and mating behavior in crickets (Gryllidae) and other Orthoptera. Misc. Publ. Mus. Zool. Univ. Mich. No. 133

7. Armitage, K. B. 1962. Social behaviour of a colony of the yellow bellied marmot (Marmota flaviventris). Anim. Behav. 10:319-31

8. Bainbridge, R. 1961. Migrations. In The Physiology of Crustacea, ed. T. H. Waterman, 2:431-63. N.Y.: Academic

9. Baker, R. R. 1968. A possible method of evolution of the migratory habit in butterflies. Phil. Trans. R. Soc. London B 253:309-41

10. Banse, K. 1964. On the vertical distribution of zooplankton in the sea. Prog. Oceanogr. 2:52-125

11. Barlow, G. W. 1964. Ethology of the Asian teleost Badis badis. V. Dynamics of fanning and other parental activities, with comments on the behavior of the larvae and postlarvae. Z. Tierpsychol. 21:99-123

12. Barth, R. H. 1970. The mating behavior of Periplaneta americana (Linnaeus) and Blatta orientalis (Linnaeus) (Blattaria, Blattinae), with notes on three additional species of Periplaneta and interspecific action of female sex pheromones. Z. Tierpsychol. 27:722-48
13. Bässler, U. 1962. Zum Einfluss von Licht und Schwerkraft auf die Ruhestellung der Stabheuschrecke (Carausius mososus). Z. Naturforsch. B 17:477-80

14. Beukema, J. J. 1968. Predation by the three-spined stickleback (Gasterosteus aculeatus L.). The influence of hunger and experience. Behaviour 31:1-126

15. Bischof, N., Scheerer, E. 1970. Systemanalyse der optischvestibulären Interaction bei der Wahrnehmung der Vertikalen. Psychol. Forsch. 34:99-181

16. Blaxter, J. H. S., Holliday, F. G. T. 1963. The behaviour and physiology of herring and other clupeids. $A d v$. Mar. Biol. 1:262-393

17. Bourne, D. W., Heezen, B. C. 1965. A wandering enteropneust from the abyssal Pacific, and the distribution of spiral tracks on the sea floor. Science 150:60-63

18. Boycott, B. B. 1954. Learning in $O c$ topus vulgaris and other cephalopods. Pubbl. Stn. Zool. Napoli 25:67-93

19. Budelmann, B. U., Wolf, H. G. 1973. Gravity response and angular acceleration receptors in Octopus vulgaris. $J$. Comp. Physiol. 85:283-90

20. Bünning, E. 1973. The Physiological Clock. Circadian Rhythms and Biological Chronometry. NY: Springer

21. Burger, J. 1974. Breeding adaptations of Franklin's gull (Larus pipixan) to a marsh habitat. Anim. Behav. 22:521-69

22. Burger, M. C. 1971, Zum Mechanismus der Gegenwendung nach mechanisch aufgezwungener Richtungsänderung bei Schizophyllum sabulosum (Julidae, Diplopoda). Z. Vergl. Physiol. 71: 219-54

23. Calow, P. 1974. Some observations on locomotor strategies and their metabolic effects in two species of freshwater gastropods, Ancylus fluviatilis Mull. and Planorbis contortus Linn. Oecologia Berlin 16:149-61

24. Campos, J. J., Langer, A., Krowitz, A. 1970. Cardiac responses on the visual cliff in prelocomotor human infants. Science 170:196-97

25. Carthy, J. D. 1958. An Introduction to the Behaviour of Invertebrates. London: George, Allen and Unwin 
26. Clayton, R. K. 1964. Phototaxis in Micro-organisms. In Photophysiology, ed. A. C. Giese, 2:50-77. NY: Academic

27. Cody, M. L. 1974. Optimization in ecology. Science 183:1156-64

28. Cooper, J. C., Hasler, A. D. 1974. Electroencephalographic evidence for retention of olfactory cues in homing coho salmon. Science 183:336-38

29. Cott, H. B. 1940. Adaptive Coloration in Animals. London: Methuen

30. Croze, H. J. 1970. Searching images in carrion crows. $Z$. Tierpsychol. Beih. $5: 1-85$

31. Crumpacker, D. W., Williams, J. S. 1973. Density, dispersion, and population structure in Drosophila pseusoob scura. Ecol. Monogr. 43:499-538

32. Dawkins, M. 1974. Behavioural analysis of coordinated feeding movements in the gastropod Lymnaea stagnalis (L.). J. Comp. Physiol. 92:255-71

33. Delius, J. D., Vollrath, F. W. 1973. Rotation compensating reflexes independent of the labyrinth. J. Comp. Physiol. 83:123-34

34. Dethier, V. G. 1957. Communication by insects: physiology of dancing. Science 125:331-36

35. Dijkgraaf, S. 1963. Nystagmus and related phenomena in Sepia officinalis. Experientia 19:29

36. Downes, J. A. 1969. The swarming and mating flight of Diptera. Ann Rev. Entomol. 14:271-98

37. Easter, St. S., Johnes, D. D., Heckenlively, D. 1974. Horizontal compensatory eye movements in goldfish (Carausius morosus). I. The normal animal. J. Comp. Physiol. 92:23-35

38. Emlen, J. M. 1966. The role of time and energy in food preferences. Am. Nat. 100:611-17

39. Emlen, St. T. 1971. Celestial rotation and stellar orientation in migratory warblers. Science 173:460-61

40. Enright, J. P. 1970 . Ecological aspects of endogenous rhythmicity. Ann. Rev. Ecol. Syst. 1:221-38

41. Ercolini, A., Scapini, F. 1974. Sun compass and shore slope in the orientation of littoral amphipodes (Talitrus saltator Montagu). Monit. Zool. Ital. (N.S.) 8:85-115

42. Farkas, S. R., Shorey, H. H., Gaston, L. K. 1974. Sex pheromones of Lepidoptera and visual cues on aerial odor-trail following by males of Pectinophora gossypiella. Ann. Entomol. Soc. Am. 67:633-38
43. Ferguson, D. E. 1971. The sensory basis of amphibian orientation Ann. NY Acad. Sci. 188:30-36

44. Forbes, L., Seward, M. J. B., Crisp, D. J. 1971. Orientation to light and the shading response in barnacles. In Fourth European Marine Biology Symposium, ed. D. J. Crisp, 539-58. Cambridge, Engl.: Cambridge Univ. Press

45. Fossey, D. 1974. Observations on the home range of one group of mountain gorillas (Gorilla gorilla Beringei). Anim. Behav. 22:568-81

46. Fraenkel, G. 1930. Die Orientierung von Schistocerca gregaria zur strahlenden Wärme. Z. Vergl. Physiol. 13: 300-13

47. Fraenkel, G., Gunn, D. L. 1940. The Orientation of Animals. Oxford: Monogr. Anim. Behav.

48. Franck, D., Hailman, E. 1972. Orientierung des Prozessionsspinners Thaumetopoea pityocampa Schilf. auf den Verpuppungswanderungen (Lep., Notodontidae). Entomol. Mitt. Zool. Mus. Hamburg 4:299-301

49. Frisch, K. V. 1965. Tanzsprache und Orientierung der Bienen Berlin-Heidelberg. NY: Springer; Engl. ed. The Dance Language and Orientation of Bees. Cambridge, Mass.: Harvard Univ. Press

50. Goodman, L. J. 1965. The role of certain optomotor reactions in regulating stability in the rolling plane during flight in the desert locust Schistocerca. gregaria. J. Exp. Biol. 42:385-407

51. Görner, P. 1973. Beispiele einer Orientierung ohne richtende Aussenreize. Fortsch. Zool. 21:20-45

52. Götz, K. G. 1968. Flight control in Drosophila by visual perception of motion. Kybernetik 4:199-208

53. Gwinner, E. 1971. Orientierung. In Grundriss der Vogelzugkunde, ed. E. Schütz, 299-348. Berlin-Hamburg: Parey

54. Gwinner, E. 1974. Endogenous temporal control of migratory restlessness in warblers. Naturwissenschaften 61:405

55. Haaker, U. 1967. Tagesthythmische Vertikalbewegungen bei Tausendfuisslern (Myriopoda, Diplopoda). Naturwissenschaften 54:346-47

56. Häntschel, W. 1975. Trace fossils and problematica. In Treatise on Invertebrate Paleontology, ed. C. Teichert, Pt. W., Suppl. 1. Boulder, Colorado: Geol. Soc. Am,; Lawrence, Kansas: Univ. Kansas Press 
57. Hagen, H.-O. 1967. Nachweis einer kinästhetischen Orientierung bei $U c a$ rapax. Z. Morphol. Oekol. Tiere 58:301-20

58. Hainsworth, F. R., Wolf, L. L. 1972. Energetics of nectar extraction in a small, high altitude, tropical hummingbird, Gelaphorus flammula. J. Comp. Physiol. 80:377-87

59. Hall, K. R. L. 1965. Ecology and behavior of baboons, patas, and vervet monkeys in Uganda. In The Baboon in Medical Research, ed. H. Vagteborg, 43-61. Austin, Texas: Texas Univ. Press

60. Hamilton, W. J. III. Watt, K. E. E. 1970. Refuging. Ann. Rev. Ecol. Syst. 1:263-86

61. Harden-Jones, F. R. 1963. The reaction of fish to moving backgrounds. J. Exp. Biol. 40:437-46

62. Hasler, A. D. 1966. Underwater Guideposts. Madison: Univ. Wisconsin Press

63. Heatwole, H. 1970. Thermal ecology of the desert dragon Amphibolurus inermis. Ecol. Monogr. 40:425-57

64. Heinrich, B. 1974. Thermoregulation in endothermic insects. Science 185: 747-56

65. Heran, H., Lindauer, M. 1963. Windkompensation und Seitenwindkorrektur der Bienen beim Flug uiber Wasser. Z. Vergl. Physiol. 47:39-55

66. Herrnkind, W. F. 1972. Orientation in shore-living arthropods, especially the sand fiddler crab. Behavior of Marine Animals, 1:1-59. NY: Plenum

67. Hisada, M., Tamasige, M., Suzuki, N. 1965. Control of the flight of the dragonfly Sympetrum darwinianum Seleys. I. Dorsophotic response. J. Fac. Sci. Hokkaido Imp. Univ. 6: Zool. 15: 568-77

68. Holst, E. V. 1950. Quantitative Messungen von Stimmungen im Verhalten der Fische. Symp. Soc. Exp. Biol. 4: $143-72$

69. Horridge, G. A. 1971. Primitive examples of gravity receptors and their evolution. In Gravity and the Organisms, ed. S. A. Gordon, M. J. Cohen, 203-21. Chicago: Univ. Chicago Press

70. Humphries, D. A., Driver, P. M. 1970. Protean defense by prey animals. Oecologia Berlin 5:285-302

71. Hutchinson, G. E. 1953. The concept of pattern in ecology. Proc. Acad. Nat. Sci. Philadelphia 105:1-12

72. Hutchinson, G. E. 1967. A Treatise on Limnology, Vol. II. NY: Plenum

73. Jacobs, W. 1952. Vergleichende Verhaltensstudien an Feldheuschrecken (Or- thoptera, Acrididae) und einigen anderen Insekten. Verh. Disch. Zool. Ges. 1952:115-38

74. Jahn, Th. 1960. Optische Gleichgewichtsregelung und zentrale Kompensation bei Amphibien, insbesondere der Erdkröte (Bufo bufo L.). Z. Vergl. Physiol. 43:119-40

75. Jander, R. 1957. Die optische Richtungsorientierung der Roten Waldameise (Formica rufa L.). Z. Vergl. Physiol. 40:162-263

76. Jander, R. 1962. The swimming plane of the crustacean Mysidium gracile (Dana). Biol. Bull. 122:380-90

77. Jander, R. 1963. Grundleistungen der Licht- und Schwerkraftorientierung von Insekten. $Z$. Vergl. Physiol. 47:381430

78. Jander, R. 1965. Die Phylogenie von Orientierungsmechanismen der Arthropoden. Verh. Dtsch. Zool. Ges. Jena 1965:266-306

79. Jander, R. 1968. Über die Ethometrie von Schlüsselreizen, die Theorie der telotaktischen Wahlhandlung und das Potenzprinzip der terminalen Cumulation bei Arthropoden. Z. Vergl. Physiol. 59:319-56

80. Jander, R. 1970. Ein Ansatz für die moderne Elementarbeschreibung der Orientierungshandlung. $Z$. Tierpsychol. 27:771-78

81. Jander, R. 1975. Interaction of light and gravity orientation in Daphnia pulex. Fortsch. Zool. 23:174-84

82. Jander, R., Daumer, K. 1974. Guideline and gravity orientation of blind termites foraging in the open (Termitidae: Macrotermes, Hospitalitermes). Insectes Soc. 21:45-69

83. Jander, R., Horn, E., Hoffmann, M. 1970. Die Bedeutung der Gelenkrezeptoren in den Beinen für die Geotaxis der höheren Insekten (Pterygota). Z. Vergl. Physiol. 66:326-42

84. Jander, R., Jander, U. 1970 . Über die Phylogenie der Geotaxis innerhalb der Bienen (Apoidea). Z. Vergl. Physiol. 66:355-68

85. Jander, R., Quadagno, D. 1974. An interval scale for measuring visual pattern discrimination of a mammal (Rattus norvegicus). Behav. Biol. 12: 93-99

86. Jander, R., Waterman, T. H. 1960. Sensory discrimination between polarized light and light intensity patterns by arthropods. J. Cell. Comp. Physiol. $56: 137-360$

87. Johnson, C. G. 1969. Migration and 
Dispersal of Insects by Flight. London: Methuen

88. Kähling, J. 1961. Untersuchungen über den Lichtsinn und dessen Lokalisation bei dem Höhlenfisch Anoptichthys jordani Hubbs and Inns (Characidae). Biol. Zentralbl. 80:439-51

89. Kaiser, H. 1974. Verhaltensgefüge und Territorialverhalten der Libelle Aeschna cyanea. Z. Tierpsychol. 34: 398-429

90. Kaufman, J. H. 1974. Social ecology of the whiptail wallaby, Macropodus parryi, in northeastern New South Wales. Anim. Behav. 22:281-369

91. Keeton, W, 1974. The orientational and navigational basis of homing in birds. Adv. Study Behav. 5:48-132

92. Kennedy, J. J., Marish, D. 1974. Pheromone-regulated anemotaxis in flying moths. Science 184:999-1001

93. Klopfer, P. H. 1973. Behavioral Aspects of Ecology. Englewood Cliffs: PrenticeHall

94. Knight-Jones, E. W. 1954. Relations between metachronism and the direction of ciliary beat in metazoa. $Q . J$. Microsc. Sci. 95:503-52

95. Krebs, J. R. 1973. Behavioral aspects of predation. In Perspectives in Ecology, ed. P. P. G. Bateson, P. H. Klopfer. NY: Plenum

96. Kühn, A. 1919. Die Orientierung der Tiere im Raum. Jena: Fischer

97. Land, M. F., Collett, T. S. 1974. Chasing behaviour of houseflies (Fannia canicularis). J. Comp. Physiol. 89: 331-57

98. Lindauer, M. 1961. Communication Among Social Bees. Cambridge, Mass.: Harvard Univ. Press

99. Linsenmair, K. E. 1969. Anemotaktische Orientierung bei Tenebrioniden und Mistkäfern (Insecta, Coleoptera). $Z$. Vergl. Physiol. 64:154-211

100. Linsenmair-Ziegler, Ch. 1970 . Vergleichende Untersuchungen zum photogeotaktischen Winkeltransponieren pterygoter Insekten. Z. Vergl. Physiol. 68:229-62

101. Ludwig, W. 1929. Untersuchungen über die Schraubenbahnen niederer Organismen. Z. Vergl. Physiol. 9: $734-801$

102. MacArthur, R. H., Connell, J. H. 1966. The Biology of Populations. NY: Wiley

103. MacArthur, R. H., Pianka, E. R. 1966. On optimal use of patchy environment. Am. Natur, 100:603-9

104. Mackinnon, J. 1974. The behaviour and ecology of wild orang-utan. Anim. Behav. 22:3-74
105. Matthews, G. V. T. 1968. Bird Navigation. Cambridge, Engl.: Cambridge Univ. Press

106. Merkel, F. W., Fischer-Klein, K. 1973. Winkel-kompensation bei Zwergwachteln (Exhaltoria chinensis). Vogelwarte 27:39-50

107. Milborrow, B. V. 1974. The chemistry and physiology of abscissic acid. Ann. Rev. Plant Physiol. 25:259-307

108. Mills, J. N., ed. 1973. Biological Aspects of Circadian Rhythms. NY: Plenum

109. Milne, L. J., Milne, M. 1965. Stabilization of the visual field. Biol. Bull. 128:285-96

110. Mittelstaedt, H. 1950. Physiologie des Gleichgewichtes bei fliegenden Libellen. Z. Vergl. Physiol. 32:422-63

111. Mohr, H. 1972. Lectures on Photomorphogenesis. NY: Springer

112. Mrosovsky, N. 1972. The water finding ability of sea turtles. Brain Behav. Evol. 5:202-25

113. Müller, K. 1974. Stream drift as a chronobiological phenomenon in running water. Ann. Rev. Syst. Ecol. 5: 309-323

114. Pardi, L. 1960 . Innate components in the solar orientation of littoral amphipods. Cold Spring Harbor Symp. Quant. Biol. 25:395-401

115. Pearre, S. 1973. Vertical migration and feeding in Sagitta elegans. Ecology $54: 300-14$

116. Pick, E. E., Lea, A. 1970. Field observations on spontaneous movements of solitary hoppers of the brown locust $L O$ custa pardalina (Walker) and behavioural differences between various colour forms. Phytophylactica 2:203-310

117. Pollard, E. C. 1971. Physical determinants of receptor mechanisms. In Gravity and the Organisms, ed. S. A. Gordon, J. Cohen, 25-34. Chicago \& London: Univ. Chicago Press

118. Pringle, J. W. S. 1948. The gyroscopic mechanism of the halteres of Diptera. Phil. Trans. R. Soc. London $B$ 233:347-84

119. Rainey, R. C. 1974. Biometerology and insect flight. Some aspects of energy exchange. Ann. Rev. Entomol. 19:407-39

120. Rensch, B. 1959. Trends towards progress of brains and sense organs. Cold Spring Harbor Symp. Quant. Biol. 24:291-303

121. Rensch, B. 1972. Neuere Probleme der Abstammungslehre. Die Transpezifische Evolution. Stuttgart: F. Enke Verlag

122. Richter, G. 1973. Field and laboratory observations on the diurnal vertical mi- 
gration of marine gastropod larvae. Neth. J. Sea Res. 7:126-34

123. Roberts, A. M. 1970. Geotaxis in motile micro-organisms. J. Exp. Biol. 53: 687-99

124. Robinson, M. H. 1973. The evolution of cryptic postures in insects with special reference to some New Guinea Tettigoniids (Orthoptera). Psyche 80:159-65

125. Rock, J. 1974. Orientation and Form. NY: Academic

126. Rosenberg, N. J. 1974. Microclimate. The Biological Environment. Chichester, Engl.: Wiley

127. Ruiter, L. de 1955. Countershading in caterpillars. Arch. Neerl. Zool. 11:285341

128. Sandeman, D. C. 1975 . Dynamic receptors in the statocyst of crabs. Fortsch. Zool. 23:185-91

129. Schaefer, K. P., Schott, D., Meyer, D. L. 1975. On the organization of neuronal circuits in the generation of the orientation response (visual grasp reflex). Fortsch. Zool. 23:199-212

130. Schneider, G. 1953. Die Halteren der Schmeissfliege (Calliphora) als Sinnesorgane und als mechanische Flugstabilisatoren. Z. Vergl. Physiol. 35: 416-58

131. Schoener, T. W. 1971. Theory of feeding strategies. Ann. Rev. Ecol. Syst. 2:369-404

132. Schöne, H. 1959. Die Lageorientierung mit Statolithenorganen und Augen. $E_{r}$ geb. Biol. 21:161-209

133. Seifarth, E., Barth, F. G. 1972. Compound slit sense organs on the spider leg: mechanoreceptors involved in kinesthetic orientation. J. Comp. Physiol. 78:76-191

134. Silver, P. H. 1974. Photoptic spectral sensitivity of the neon tetra (Paracheirodon innesi. Myers) found by the use of a dorsal light reaction. Vision Res. 24:329-34

135. Smith, J. N. M. 1974. The food searching behaviour of two European thrushes. II. The adaptiveness of the search pattern. Behaviour 49:1-61

136. Southwood, T. R. E. 1966. Ecological Methods, London: Methuen

137. Stang, G. 1972. Die zentralnervöse Verrechnung optischer Afferenzen bei der Gleichgewichtshaltung von Fischen. $J$. Comp. Physiol. 80:95-118

138. Stasko, A. B. 1971. Review of field stud- ies on fish orientation. Proc. NY Acad. Sci. 188:12-28

139. Stein, A., Schöne, H. 1972. Über das Zusammenspiel von Schwereorientierung und Orientierung zur Unterlage beim Flusskrebs. Verh. Dtsch. Zool. Ges. 65:225-28

140. Sudd, J. H. 1967. An Introduction to the Behaviour of Ants. London: Arnold

141. Tsang, N., Macnab, R., Koshland, D. E. 1973. Common mechanisms for repellents and attractants in bacterial chemotaxis. Science 181:60-63

142. Vielmetter, W. 1958. Physiologie des Verhaltens zur Sonnenstrahlung bei dem Tagfalter Argynnis paphia L. I. Untersuchungen im Freiland. Insect Physiol. 2:13-37

143. Walk, R. D., Walter, C. P. 1973. Effect of visual deprivation on depth discrimination of hooded rats. J. Comp. Physiol. Psychol. 85:559-63

144. Wallraff, H. G. 1972. An approach toward an analysis of pattern recognition involved in the stellar orientation of birds. In Animal Orientation and Navigation, ed. S. R. Galler, K. SchmidtKoenig, G. J. Jacobs, R. E. Belleville, 211-22. Washington DC: NASA SP262

145. Walls, G. L. 1962. The evolutionary history of eye movements. Vision Res. 2:69-80

146. Warburton, K. 1973. Solar orientation in the snail Nerita plicata (Prosobranchia: Neritacea) on a beach near Watamu, Kenya. Mar. Biol. 23;93-100

147. Weiss, P. 1925. Tierisches Verhalten als "Systemreaktion:" Die Orientierung der Ruhestellung von Schmetterlingen (Vanessa) gegen Licht- und Schwerkraft. Biol. Gen. 1:167-248. Transi. 1959. Yearb. Soc. Gen. Syst. Res. $4: 1-44$

148. Werner, E. E., Hall, D. J. 1974. Optimal foraging and size selection of prey by blue gill sunfish (Lepomis macrochirus). Ecology 55:1042-52

149. Wickler, W., Seibt, U. 1972. Zur Ethologie der Stielaugenfliegen (Diptera, Diopsidae). Z. Tierpsychol. 31: $113-30$

150. Wiltschko, H., Gwinner, E. 1974. Evidence for innate magnetic compass in garden warblers. Naturwissenschaften 61:406

151. Youthed, G. J., Moran, V. C. 1969. Pit construction by myrmeleontid larvae. $J$. Insect Physiol. 15:867-75 


\section{CONTENTS}

The Impact of Robert MacArthur on Ecology, Stephen D. Fretwell 1

Ecological Significance of IMPRINTING and EARLy Learning. Klaus Immelmann $\quad 15$

The Rumen Microbial Ecosystem, $R$. E. Hungate 39

Structure and Climate in Tropical Rain Forest, Egbert Giles Leigh, Jr. $\quad 67$

Cannibalism in Natural Populations, Laurel R. Fox 87

Demographic Consequences of Infanticide in Man, Mildred $\begin{array}{ll}\text { Dickeman } & 107\end{array}$

Energetics of Pollination, Bernd Heinrich 139

Ecological Aspects of Spatial Orientation, Rudolf Jander 171

Spectral Analysis in Ecology, Trevor Platt and Kenneth L. Denman 189

The Population Biology of Coral Reef Fishes, Paul R. Ehrlich 211

Late Quaternary Chimatic Change in Africa, D. A. Livingstone 249

Experimental Studies of THe Niche, Robert $K$. Colwell and Eduardo $\begin{array}{ll}R \text {. Fuentes } & 281\end{array}$

Simulation Models of Ecosystems, Richard G. Wiegert 311

Modes of Animal Speciation, Guy L. Bush 339

Butterfly Ecology, Lawrence E. Gilbert and Michael C. Singer 365 INDEXES

AUTHOR INDEX 399

SubJect INDEX $\quad 411$

Cumulative Index of Contributing Authors, Volumes 2-6 419

Cumulative Index of Chapter Titles. Volumes 2-6 420 